\title{
溶接不良によるステンレス製給湯タンクの腐食割れ*
}

筒井 光範**, 山田 隆志**

** 名古屋市工業研究所

\section{Stress Corrosion Cracking in Hot Water Tank of Type 304 Steel caused from a Weld Defect}

\author{
Mitsunori Tsutsui** and Takashi Yamada** \\ **Nagoya Municipal Industrial Research Institute
}

\begin{abstract}
Stress corrosion cracking was found in Type 304 steel tank for hot water with $\mathrm{Cl}^{-}$content of $19 \mathrm{ppm}$ and temperature of $80^{\circ} \mathrm{C}$. It was learned that poor penetration in butt welding left a gap of $40 \mu \mathrm{m}$ in the tank wall, which would behave as a corrosion crevice to initiate cracks under residual stresses.
\end{abstract}

\section{1.はじめに}

ステンレス鋼は高温水溶液中ではわずか数 ppm と微 量の塩化物イオンの存在によっても応力腐食割れを起こ す1。るむた溶接が施されている場合には熱影響部におい て粒界腐食割れが起こるほか，とくにシーム溶接の場合 には構造的すきまでの腐食から応力腐食割れに発展す る2)ことが知られている。そのためステンレス製給湯タ ンクの応力腐食割れの防止対策として，(1) 電気防食,

（2）低炭素鋼 (304L など）の使用，（3）すきまを形成 するシーム溶接をさけ, 突合せ溶接の採用, が計られてい る。しかしながら, 液温も塩化物イオン濃度も比較的低 いマイルドな温水環境に执いては，(1)，(2) の対策がと られていない場合が多く，しばしば腐食割れ事故が経験 される。このような場合の割れでは, 溶接部近傍に起こ るものが圧倒的に多い。タンク内部からの腐食の原因と しては, 溶接による残留応力, 熱影響部でのクロム炭化 物の析出に伴う耐食性の劣化, けい酸塩などの堆積付着 物によるすきまの形成などが考兄られるが，以下に述べ るような突合せ溶接の不良に起因する腐食割れ事例も見 逃すことはできない。

* 腐食防食協会装置材料のPerformance 研究会第 8 回会議で発表

** 干456 名古屋市熱田区六番三丁目 4-41 (Rokuban 3-4-41, Atsuta-ku, Nagoya-shi, 456 Japan)

\section{2. 使用状況と腐食状態}

給湯タンクは厚さ $4 \mathrm{~mm}$ のSUS 304 の薄板を突合せ 溶接したもので, 使用後約 3 ケ月で漏水事故を起こし, 肉盛補修をしたところ，さらに激しい水漏れを生じた。 使用された水は井戸水であり，これに 10\% の次亜塩素
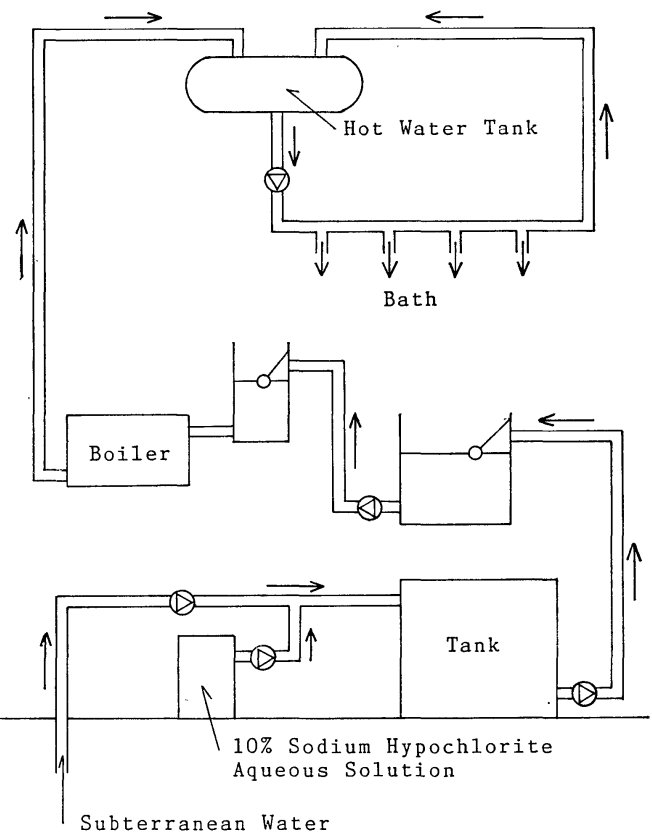

Fig. 1 Schematic drawing of the hot water system. 


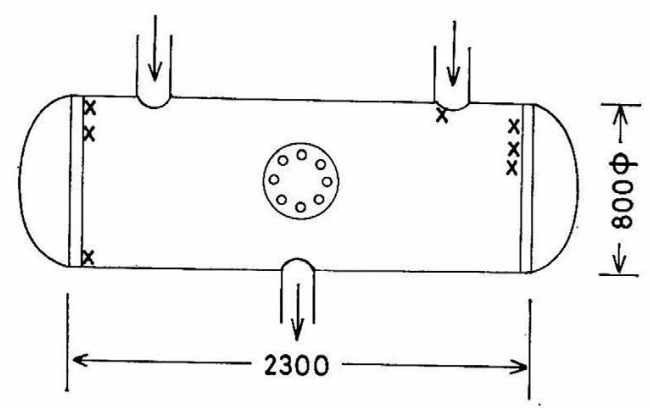

Fig. 2 The hot water tank which suffered corrosion crackings near the welds at the locations as shown by (x).

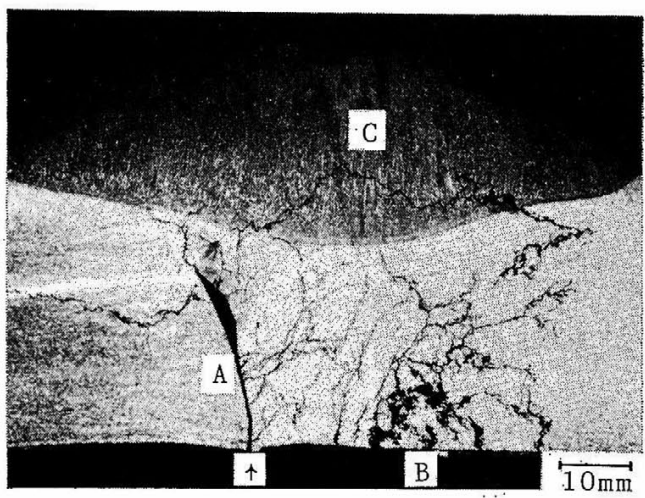

Fig. 3 (a) Stress corrosion cracks, A, from the crevice with those, $\mathbf{B}$, from the other portion on inner surface of the tank. The bead weld, $\mathrm{C}$, was patched after a water leak, which resulted in severe leakage.

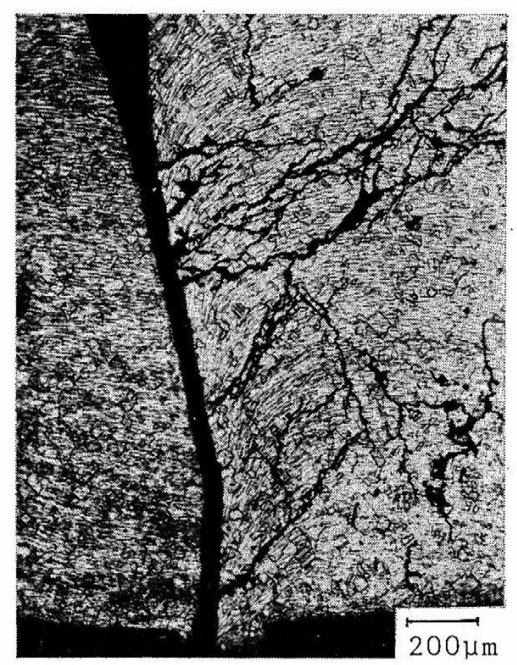

Fig. 3 (b) Enlarged view of the cracks A in Fig. 3(a). The cracks started from the crevice with a gap of about $40 \mu \mathrm{m}$ which had been left open because of a malpractice in butt welding.

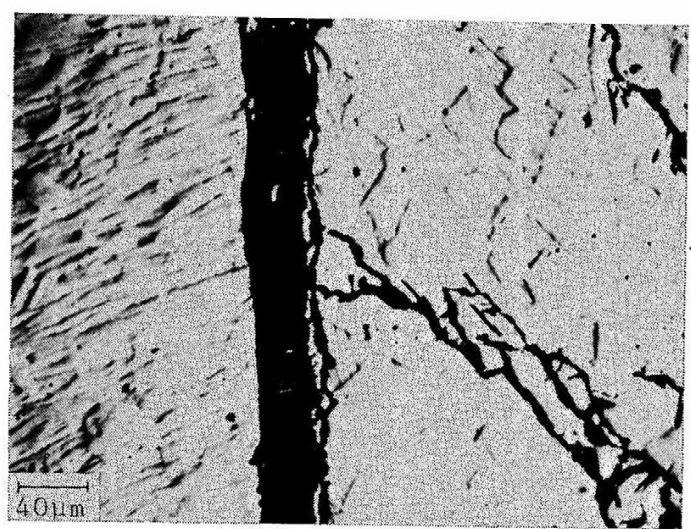

Fig. 4 (a) Back-scattered electron image for the crevice and cracks.

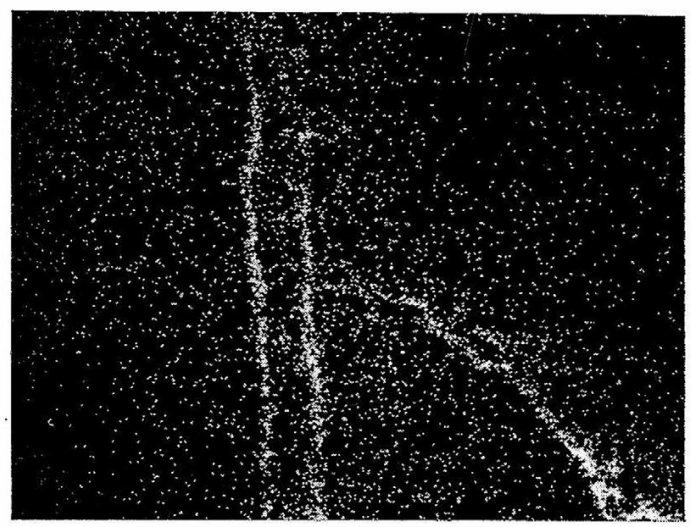

Fig. 4 (b) X-ray image for $\mathrm{C} 1 \mathrm{~K} \alpha$ of the same area as Fig. 4(a).

酸ナトリウム水溶液を約 $1.4 \times 10^{6}: 1$ の割合で混合し, ボイラーで加熱後タンク内住留し, 常時約 $80^{\circ} \mathrm{C}$ の温 度で給湯されるようになっていた。Fig. 1 に給湯シス テムの概略図を示す。

破損箇所は Fig. 2 飞示す上らに鏡板の溶接部に集中 し，一部パイプの溶接部にも認められた。液温が $80^{\circ} \mathrm{C}$ と低く, 温湯中の塩化物イオン濃度も約 $19 \mathrm{ppm}$ と低 かったこと，かつ破損までの期間が 3 ケ短いことか ら，その腐食原因を顕微鏡及びX線マイクロアナライザ 一によって調べた。

\section{3. 顕微鏡試験及びX 線マイクロアナライザーによる 分析}

Fig. 3 (a) は鏡板溶接部の嘍れを示す。写真から溶接 は不完全であることがわかる。矢印 $(\rightarrow)$ で示す突合せ 部に拈いて幅約 $40 \mu \mathrm{m}$ 程度のすきまが形成されている。 割れはこのすきま部及びタンク内面の他の箅所一一溶接 部すなわちすきまの右方に多い一から発生している。 Fig. 3 (a) のAの割れは貫粒型の典型的な応力腐食割れ の形態を示している。な和ここで図中の B と C の割れ 


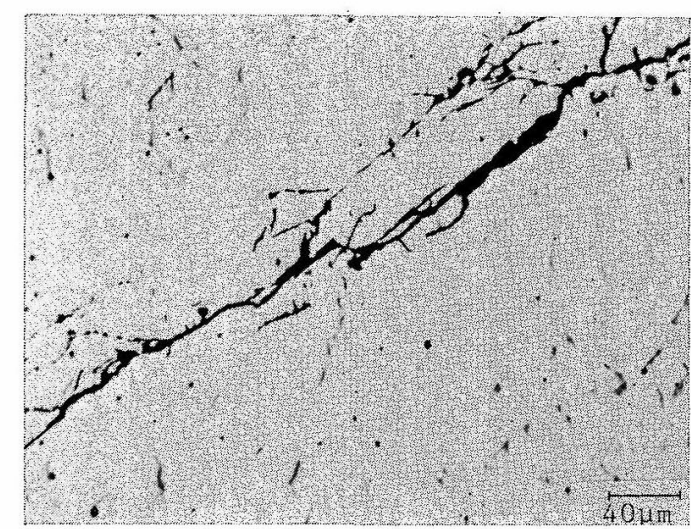

Fig. 5 (a) Back-scattered electron image for the cracks near the pointed end.

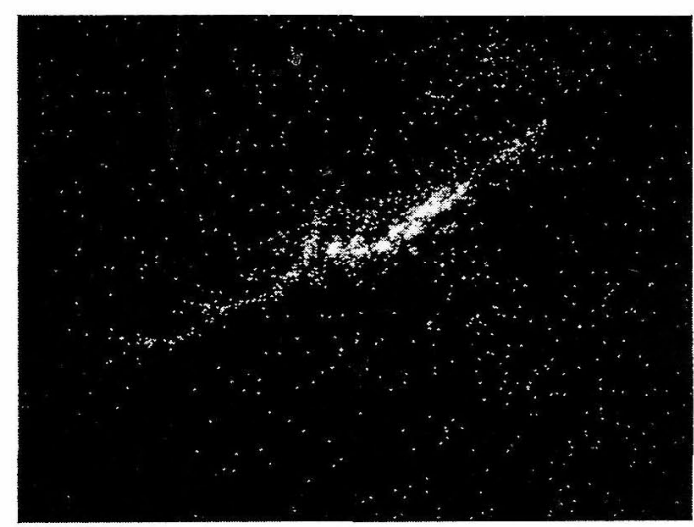

Fig. 5 (b) X-ray image for $\mathrm{C} 1 \mathrm{~K} \alpha$ of the same area as Fig. 5 (a).

は，補修後の漏水状況から，肉盛補修及び試料採取時の ガス切断に起因するものと考えられた。

矢印 $(\rightarrow)$ 部を拡大した Fig. $3($ b) のすきま右側の組 織の流れから，板は切断時に強固に塑性変形をらけて拉 りこの部分での残留応力はかなり高いものと推察され
る。

つぎに腐食割れの部分をX線マイクロアナライザーに よって定性分析したところ Cl と微量の $\mathrm{S}$ 方検出され た。

Fig. 4(a)，(b) は溶接不良によって形成されたすき ま部の面分析結果を示す。 $\mathrm{Cl}$ はすきま及び割れ内部に 濃縮している。Fig. 5 (a)，(b) は割れの先端近くの面 分析結果を示す。 $\mathrm{Cl}$ は割れの起点と同様に割れの内部 にも濃縮している。タンク内部の他の籄所から発生し た割れについてる分析したところ，Cl の濃縮は割れ内 部では認められたものの, 内表面上に存在したであるら 堆積物下については明瞭に確認することはできなかっ た。

\section{4. まとめ}

給湯タンクの扁食割れ原因としては, 溶接が不完全で あったために突合せ部に構造的すきまが形成されここ ですきま腐食が起こり，応力腐食割れに進展したものと 推察された。突合せの端面が切断時に塑性变形を受けて 牤り，それが溶融しないでそのま亦残されたため，残留 応力が除去されず，これに溶接による残留応力が加わっ たことも，割れの応力条件を厳しくしたと思われる。溶 接を完全に行うことによって，上記のよらな腐食割れは 防ぐことが出来る。タンクの径が小さく内部からの溶接 が不问能な場合には，たと充板厚が薄くても，突合せ端 面で開先をとって溶接するといらことる施工時に徹底す る必要がある。

(Received April 10, 1986)

\section{文献}

1) 須永寿夫：ステンレス, 18 [8] 24 (1974).

2) 増尾 誠, 小野 寛, 大橋 延夫: 防食技術, 26, 573 (1977). 